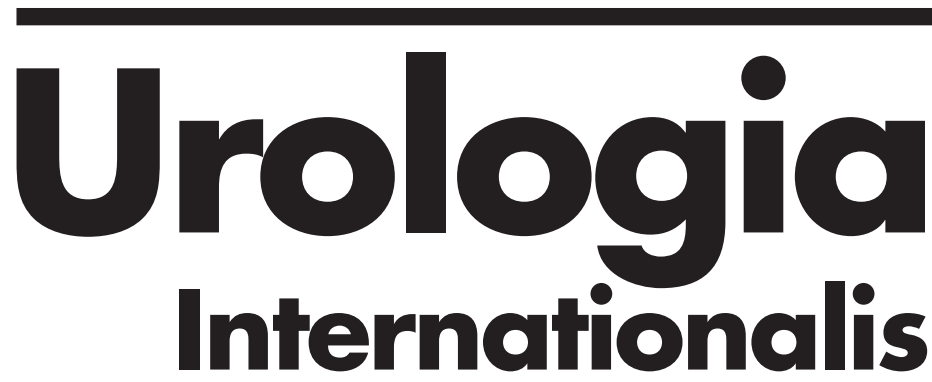

Founded 1955 by G. Peter A. Narath and Heinrich Heusser

Successors: G. Mayor (1968-1987); D. Hauri (1988-2005)

\section{Editors}

M.P. Wirth, Dresden

M. Porena, Perugia

O.W. Hakenberg, Rostock

D. Castro-Diaz,

Santa Cruz de Tenerife

\section{Editorial Committee}

R. Ackermann, Düsseldorf

Y. Aso, Tokyo

F.M.J. Debruyne, Arnhem

D.G. Hatzichristou, Thessaloniki

Ph. Jaeger, Uxbridge

G. Jakse, Aachen

R. Mundy, London

J. Nordling, Herlev

P. Rigatti, Milano

H. Rübben, Essen

F. Schröder, Rotterdam

G. Watson, Eastbourne

W. Weidner, Giessen

\title{
Board of Reviewing Editors
}

P. Albers, Kassel

G.L. Andriole, St. Louis

W. Artibani, Verona

M. Bagshaw, Stanford

G. Baretton, Dresden

P. Bassi, Padova

M.A. Brausi, Modena

M. Butz, Nürnberg

P. Caione, Roma

K. Dreikorn, Bremen

I. Eardley, Leeds

P. Fornara, Halle

B. Frea, Novara

J.P. Gearhart, Baltimore

W. Horninger, Innsbruck

G. Janetschek, Linz

J.R. Kalden, Erlangen
M.M. Karram, Cincinnati

J.N. Krieger, Seattle

M. Laniado, Dresden

M. Lazzeri, Firenze

V.R. Marshall, Adelaide

M.J. Mihatsch, Basel

E. Montanari, Milano

G. Morgia, Messina

G. Nicita, Firenze

R.T.D. Oliver, London

B. Schmitz-Dräger, Fürth

S. Siracusano, Trieste

N. Sofikitis, Ioannina

M.S. Soloway, Miami

A. Tubaro, Roma

F. Verrey, Zürich

H. Villavicencio, Barcelona 
S. Karger

Medical and Scientific Publishers

Basel $\cdot$ Freiburg $\cdot$ Paris $\bullet$ London •

New York $•$ Bangalore $\cdot$ Bangkok

Shanghai $\cdot$ Singapore $\cdot$ Tokyo $\cdot$ Sydney
Disclaimer

The statements, options and data contained in this publication are solely those of the individual authors and contributors and not of the publisher and the editor(s). The appearance of advertisements in the journal is not a warranty, endorsement or approval of the products or services advertised or of thei effectiveness, quality or safety. The publisher and the editor(s) disclaim responsibility for any injury to persons or property resulting from any ideas, methods, instructions or products referred to in the content or advertisements.

Drug Dosage

The authors and the publisher have exerted every effort to ensure that drug selection and dosage set forth in this text are in accord with current recommendations and practice at the time of publication. However, in view of ongoing research, changes in government regulations, and the constant flow of information relating to drug therapy and drug reactions, the reader is urged to check the package insert for each drug for any change in indications and dosage and for added warnings and precautions. This is particularly important when the recommended agent is a new and/or infrequently employed drug.
All rights reserved.

No part of this publication may be translated into other languages, reproduced or utilized in any form or by any means, electronic or mechanical, including photocopying, recording, microcopying, or by any information storage and retrieval system, without permission in writing from the publisher or, in the case of photocopying, direct payment of a specified fee to the Copyright Clearance Center (see 'General Information')

(C) Copyright 2008 by S. Karger AG,

P.O. Box, CH-4009 Basel (Switzerland)

Printed in Switzerland

on acid-free and non-aging paper (ISO 9706) by

Reinhardt Druck, Basel

\section{KARGER}




\section{Urologia \\ Internationalis}

No. 1

Review

1 Update on Flexible Ureteroscopy

Buscarini, M.; Conlin, M. (Portland, Oreg.)

Original Papers

8 Clinical and Functional Results after Continent Cutaneous Urinary Diversion with the Ileal Double-T-Pouch

Seifert, H.-H.; Obaje, A.; Müller-Mattheis, V.; Müller, M.; Grimm, M.-O.; Ackermann, R. (Düsseldorf)

13 The Importance of Palliative Care in Urology Brierly, R.D.; O'Brien, T.S. (London)

19 Do Weather Conditions Influence the Onset of Renal Colic? A Novel Approach to Analysis Boscolo Berto, R.; Dal Moro, F. (Padua); Abate, A. (Berkeley, Calif.); Arandjelovic, G.; Tosato, F. (Padua); Bassi, P. (Rome)

26 Modified Transurethral Incision of the Bladder Neck Treating Primary Bladder Neck Obstruction in Young Men: A Method to Improve Voiding Function and to Preserve Antegrade Ejaculation

Yang, S.S.-D.; Tsai, Y.-C. (Hualien); Chen, J.-J.; Peng, C.-H. (Taipei); Hsieh, J.-H. (Chungli); Wang, C.C. (Taipei/Chungli)

31 Clinical and Radiological Features of Adrenal Cysts Erbil, Y.; Salmaslıŏglu, A.; Barbaros, U.; Bozbora, A.; Mete, Ö.; Aral, F.; Özarmağan, S. (Istanbul)

37 Does Position Affect Uroflowmetry Parameters in Women? Gupta, N.P.; Kumar, A.; Kumar, R. (New Delhi)

41 Presentation of Female Urethral Diverticulum Is Usually Not Typical

Chang, Y.-L.; Lin, A.T.L.; Chen, K.-K. (Taipei)

46 Cadaveric Fascia Lata versus Intravaginal Slingplasty for the Pubovaginal Sling: Surgical Outcome, Overall Success and Patient Satisfaction Rates

Basok, E.K.; Yildirim, A.; Atsu, N.; Basaran, A.; Tokuc, R. (Istanbul)

52 Prevalence of Positive Potassium Sensitivity Test Which Is an Indicator of Bladder Epithelial Permeability Dysfunction in a Fixed Group of Turkish Women

Sahinkanat, T.; Güven, A.; Ekerbicer, H.; Aral, M. (Kahraman Maras)

57 Overactive Bladder in Children Should Be Strictly Differentiated from Monosymptomatic Nocturnal Enuresis Kajiwara, M.; Kato, M. (Hiroshima); Mutaguchi, K. (Oita); Usui, T. (Hiroshima)
62 Effect of Laparoscopic Hysterectomy on the Vascularization of the Lower Urinary Tract

Liu, C.-M.; Tsai, E.-M.; Hsu, S.-C.; Wu, C.-H.; Wang, C.-L.; Long, C.-Y. (Kaohsiung)

68 Comparison of Chromogranin A, Insulin-Like Growth Factor 1 and Prostate-Specific Antigen Serum Markers in Prostate Adenocarcinoma and Benign Prostatic Hyperplasia

Sciarra, A.; Gentile, V.; Monti, S.; Dattilo, C.; Autran Gomez, A.; Salciccia, S. Proietti Pannunzi, L.; Toscano, V.; Di Silverio, F. (Rome)

74 Intravesical Bacillus Calmette-Guérin Therapy for T1 Superficial Bladder Cancer

Demkow, T. (Warsaw); Alter, A. (Radom); Wiechno, P. (Warsaw)

80 Comparative Study of Graft Nephrectomy in Pre-Cyclosporine and Cyclosporine Era

Adhikary, S.D.; Viswaroop, S.B.; Kekre, N.S.; Gopalakrishnan, G. (Vellore)

84 Verapamil Attenuates Renal Tubular Apoptosis in Response to Partial Unilateral Ureteral Obstruction

Topcu, S.O.; Erbagci, A.; Erturhan, S.; Yagci, F.; Ucak, R. (Kolejtepe/Gaziantep)

90 Cell Proliferation and DNA Content in Rat Urothelial Lesions after Repeat Intravesical Instillations of Mitomycin C and Bacillus Calmette-Guérin

Oliveira, P. (Vila Real); Palmeira, C. (Porto); Colaço, A. (Vila Real); De la Cruz P, L.F. (Lugo); Lopes, C. (Porto)

98 Polyorchidism: Presentation of 2 Cases, Review of the Literature and a New Management Strategy

Khedis, M.; Nohra, J.; Dierickx, L.; Walschaerts, M.; Soulié, M.; Thonneau, P.F.; Plante, P.; Huyghe, E. (Toulouse)

Case Reports

102 Malignant Epithelioid Renal Angiomyolipoma Involving the Inferior Vena Cava in a Patient with Tuberous Sclerosis Moudouni, S.M.; Tligui, M.; Sibony, M.; Doublet, J.D.; Haab, F.; Gattegno, B.; Thibault, P. (Paris)

[Clinical Comment by Michael Froehner, Dresden]

105 Repair of Hypospadiac Urethral Duplication with Dismembered Urethroplasty

Deniz, N.; Kirac, M.; Camtosun, A.; Irkilata, L.; Tan, M.O. (Ankara)

108 Hemangioma of the Prostatic Urethra: Holmium Laser Treatment

Ponce de León, J.; Arce, J.; Gausa, L.; Villavicencio, H. (Barcelona)

111 Cutaneous Metastases in Renal Cell Carcinoma

Bujons, A.; Pascual, X.; Martínez, R.; Rodríguez, O.; Palou, J.; Villavicencio, H. (Barcelona)

\section{KARGER}

Fax +41613061234 E-Mail karger@karger.ch www.karger.com

\section{2008 S. Karger AG, Basel}

Access to full text and tables of contents, including tentative ones for forthcoming issues: www.karger.com/uin_issues 
No. 2

Review

113 Mathematical Models for Prognostic Prediction in Patients with Renal Cell Carcinoma

Galfano, A.; Novara, G.; Iafrate, M.; Cavalleri, S. (Padua); Martignoni, G. (Verona); Gardiman, M.; D’Elia, C. (Padua); Patard, J.J. (Rennes);

Artibani, W.; Ficarra, V. (Padua)

Original Papers

124 TA T1 Low and Intermediate Transitional Cell Carcinoma of the Bladder: Recurrence Rates and the Timing of Check Cystoscopies within the First Year

Guney, S.; Guney, N.; Canogullari, Z.; Ergenekon, E. (Istanbul)

129 Simple Stratification of Survival Using Bone Scan and Serum C-Reactive Protein in Prostate Cancer Patients with Metastases

Nakashima, J.; Kikuchi, E.; Miyajima, A.; Nakagawa, K.; Oya, M.; Ohigashi, T.; Murai, M. (Tokyo)

134 Testosterone Levels in Benign Prostatic Hypertrophy and Prostate Cancer

Mearini, L.; Costantini, E.; Zucchi, A.; Mearini, E.; Bini, V.; Cottini, E.; Porena, M. (Perugia)

141 Management of Cystinuric Patients: An Observational, Retrospective, Single-Centre Analysis

Ahmed, K.; Khan, M.S.; Thomas, K.; Challacombe, B.; Bultitude, M.; Glass, J.; Tiptaft, R.; Dasgupta, P. (London)

145 Biopsy-Derived Gleason Artifact and Prostate Volume: Experience Using Ten Samples in Larger Prostates Sciarra, A.; Autran Gomez, A.; Salciccia, S.; Dattilo, C.; Ciccariello, M.; Gentile, V.; Di Silverio, F. (Rome)

151 Long-Term Experience with an Anatomical Anterograde Approach to Radical Prostatectomy: Results in Terms of Positive Margin Rate

Sciarra, A.; Gentile, V.; De Matteis, A.; Dattilo, C.; Autran Gomez, A.-M.; Salciccia, S.; Di Silverio, F. (Rome)

157 Treatment for Chronic Prostatitis/Chronic Pelvic Pain Syndrome: Levofloxacin, Doxazosin and Their Combination Jeong, C.W.; Lim, D.J.; Son, H. (Seoul); Lee, S.E. (Seongnam); Jeong, H. (Seoul)

162 Tadalafil and Fluoxetine in Premature Ejaculation: Prospective, Randomized, Double-Blind, Placebo-Controlled Study Mattos, R.M.; Marmo Lucon, A.; Srougi, M. (São Paulo)

166 Prevalence of Cryptorchidism, Retractile Testis and Orchiopexy in School Children

Inan, M.; Aydiner, C.Y.; Tokuc, B.; Aksu, B.; Ayhan, S.; Ayvaz, S.; Ceylan, T. (Edirne)

172 Results of Varicocelectomy in Patients with Isolated Teratozoospermia

Çakan, M.; Bakirtas, H. (Ankara); Aldemir, M. (Polatlı); Demirel, F.; Altug, U. (Ankara)

177 Effect of Finasteride Treatment on Suburethral Prostatic Microvessel Density in Patients with Hematuria Related to Benign Prostate Hyperplasia

Memis, A.; Ozden, C.; Ozdal, O.L.; Guzel, O.; Han, O.; Seckin, S. (Ankara)

181 Does Sildenafil Affect Uroflowmetry Values in Men with Lower Urinary Tract Symptoms Suggestive of Benign Prostatic Enlargement?

Güler, C.; Tüzel, E.; Doğantekin, E.; Kızıltepe, G. (Afyon)

186 Serum PSA and Percent Free PSA Value Changes after Antibiotic Treatment. A Diagnostic Method in Prostate Cancer Suspects with Asymptomatic Prostatitis Kobayashi, M.; Nukui, A.; Morita, T. (Tochigi)
193 Alteration in Contractile Responses in Human Detrusor Smooth Muscle from Obstructed Bladders with Overactivity Kosan, M.; Tul, M.; Ozturk, B.; Hafez, G.; Inal, G.; Cetinkaya, M. (Ankara)

201 Effect of Curcumin on Ipsilateral and Contralateral Testes after Unilateral Testicular Torsion in a Rat Model Basaran, U.N.; Dokmeci, D.; Yalcin, O.; Inan, M.; Kanter, M.; Aydogdu, N.; Turan, N. (Edirne)

Surgical Technique

208 Extravesical Seromuscular Ureteroneocystostomy: An Effective and Simple Operation for Treatment of Vesicoureteral Reflux

Salehipour, M.; Jalaeian, H.; Shirazi, M.; Rajabi, M.J. (Shiraz)

Case Reports

212 Peripheral Primitive Neuroectodermal Tumor Arising from the Seminal Vesicle

Lawrentschuk, N.; Appu, S.; Chao, I.; Chan, Y.; Rogerson, J., Davis, I.D (Heidelberg)

[Clinical Comment by M. Froehner, Dresden]

217 Pulmonary Thromboembolism Secondary to Left Spermatic Vein Thrombosis: A Case Report Castillo, O.A.; Diaz, M.; Vitagliano, G.J.; Metrebian, E. (Santiago)

219 Blood Eosinophilia, Corticoadrenal Insufficiency and Eosinophilic Cystitis

Lin, H.-H. (Taichung); Yen, T.-H. (Linkou); Huang, C.-C. (Taichung); Chiang, Y.-J. (Linkou); Kuo, H.-L. (Taichung)

222 Intrinsic Endometriosis of Ureter and Bladder in Young Women without Gynecological Symptoms Leonhartsberger, N.; Zelger, B.; Rehder, P. (Innsbruck)

No. 3

Obituary

225 Steven Karger (1959-2008)

Karger, T. (Basel)

Review

226 Quality of Life after Radical Prostatectomy

Liatsikos, E.N.; Assimakopoulos, K. (Patras); Stolzenburg, J.-U. (Leipzig)

Original Papers

231 Predictors of Quality of Life after Radical Treatment for Prostate Cancer

Gacci, M.; Lapini, A.; Serni, S.; Livi, L.; Paiar, F.; Detti, B.; Simontacchi, G.; Vittori, G.; Giubilei, G.; Mariani, M.; Palli, D.; Carini, M. (Florence)

237 Learning Curve and Preliminary Experience with da Vinci-Assisted Laparoscopic Radical Prostatectomy Artibani, W.; Fracalanza, S.; Cavalleri, S.; Iafrate, M.; Aragona, M.; Novara, G.; Gardiman, M.; Ficarra, V. (Padua)

245 Diagnostic Value of Serum Ghrelin Levels in Prostate Cancer Mungan, N.A.; Eminferzane, S.; Mungan, A.G.; Yesilli, C.; Seckiner, I.; Can, M.; Ayoglu, F.; Akduman, B. (Zonguldak)

249 Histopathologically Proven Prevention of Post-Prostatectomy Cavernosal Fibrosis with Sildenafil Iacono, F.; Prezioso, D.; Somma, P.; Chierchia, S.; Galasso, R.; Micheli, P. (Naples)

253 Comparison of Lidocaine Suppositories and Periprostatic Nerve Block during Transrectal Prostate Biopsy Szlauer, R.; Götschl, R.; Gnad, A.; Meissner, P.; Paras, L.; Schmeller, N.T.; Fink, K.G. (Salzburg) 
257 Lymphocyte Subsets in Renal Transplant Recipients with de novo Genitourinary Malignancies

Guichard, G.; Rebibou, J.M.; Ducloux, D.; Simula-Faivre, D.; Tiberghien, P. Chalopin, J.M.; Bittard, H.; Saas, P.; Kleinclauss, F. (Besançon)

264 Clinical Value of PTEN in Patients with Superficial Bladder Cancer

Han, K.S.; Jeong, I.G.; Joung, J.Y.; Yang, S.O.; Chung, J.; Seo, H.K.; Kwon, K.S.; Park, W.S.; Lee, K.H. (Goyang)

270 Are There Any UPP Changes in Women with Stress Urinary Incontinence after Pelvic Floor Muscle Exercises?

Zahariou, A.; Karamouti, M.; Georgantzis, D.; Papaioannou, P. (Volos)

275 Transobturator Tape in the Management of Female Stress Incontinence: Clinical Outcomes at Medium Term Follow-Up Kocjancic, E.; Crivellaro, S. (Novara); Oyama, I.A. (Philadelphia, Pa.); Singla, A. (Detroit, Mich.); Ranzoni, S. (Novara); Carone, R.; Manassero, A. (Turin); Gontero, P.; Frea, B. (Novara)

279 Endoscopic Treatment of Vesicoureteral Reflux with Polydimethylsiloxane in Adults: Do Location and Appearance of the Ureteric Orifice Have a Role in the Success Rates? Basok, E.K.; Yildirim, A.; Atsu, N.; Gocer, S.; Tokuc, R. (Istanbul)

283 The Use of Artificial Neural Networks in Decision Support in Vesicoureteral Reflux Treatment

Seckiner, I.; Seckiner, S.U.; Erturhan, S.; Erbagci, A.; Solakhan, M.; Yagci, F. (Gaziantep)

287 Internet Survey of Management Trends of Urethral Strictures Rapp, D.E.; Chanduri, K.; Infusino, G.; Hoda, Z.A.; Orvieto, M.A. (Chicago, Ill.); Elliott, S.P. (Minneapolis, Minn.); Alsikafi, N.F. (Chicago, Ill.)

290 Editorial Comment Oosterlinck, W. (Ghent)

292 The Hemostatic Properties of Transurethral Plasmakinetic Resection of the Prostate: Comparison with Conventional Resectoscope in an ex vivo Study

Qu, L. (Wuhan/Guangzhou); Wang, X.; Huang, X.; Zhang, Y.; Zeng, X. (Guangzhou)

296 Association between Erectile Dysfunction and Lower Urinary Tract Symptoms due to Benign Prostatic Hyperplasia in Nigerian Men

Ikuerowo, S.O.; Akindiji, Y.O.; Akinoso, O.A.; Akinlusi, F.M.; Esho, J.O. (Ikeja)

300 Diagnostic Accuracy of Urinary Creatinine Concentration in the Estimation of Differential Renal Function in Patients with Obstructive Uropathy

Al-Hunayan, A.; Al-Ateeqi, A.; Kehinde, E.O.; Thalib, L.; Loutfi, I. Mojiminiyi, O.A. (Safat)

306 Laparoscopic Pyeloplasty with Concomitant Pyelolithotomy Is It an Effective Mode of Treatment?

Srivastava, A.; Singh, P.; Gupta, M.; Ansari, M.S.; Mandhani, A.; Kapoor, R.; Kumar, A.; Dubey, D. (Lucknow)

310 Grading of Classical Testicular Microlithiasis Has No Effect on the Prevalence of Associated Testicular Tumors Sanli, O.; Kadioglu, A.; Atar, M.; Acar, O.; Nane, I.; Kadioglu, A. (Istanbul)

317 Decreased Incidence of Appendix Testis in Cryptorchidism with Intraoperative Survey

Józsa, T.; Csízy, I.; Kutasy, B.; Cserni, T.; Flaskó, T. (Debrecen)

321 Evaluation of Penile Rigidity with Color Doppler Flow Imaging in Chinese Patients with Erectile Dysfunction

Xuan, X.; Wang, D. (Guangzhou); Sun, P. (Jinan); Mei, H. (Guangzhou)

Case Reports

325 Infected Retroperitoneal Cystic Lymphangioma Masquerading as Psoas Abscess

Pratap, A.; Tiwari, A.; Sah, B.P.; Sinha, A.K.; Shakya, V.C. (Dharan);

Niels, K.G. (Maastricht)

328 Clinical Comment

Conceptión Masip, T. (Santa Cruz de Tenerife)
329 Cancer in Kidney Transplantation

Zani, D.; Simeone, C.; Antonelli, A.; Bettini, E.; Moroni, A.;

Cosciani Cunico, S. (Brescia)

332 Renal Artery Pseudoaneurysm Occurring after Laparoscopic Partial Nephrectomy

Shigeta, M.; Mita, K.; Shoji, K.; Marukawa, K.; Toyota, N.; Usui, T. (Hiroshima)

335 Probability of Ten-Year Survival in Metastatic Renal Cell Carcinoma

Salagierski, M.; Salagierski, M.; Salagierska-Barwińska, A.; Sosnowski, M. (Łódź)

338 Fibroepithelial Polyp of Distal Ureter with Periodic Prolapse into Bladder

Baltogiannis, D.; Kafetzoulis, A.; Giannakis, D. (Ioannina); Saito, M.; Miyagawa, I. (Yonago); Sofikitis, N. (Ioannina/Yonago)

No. 4

Review

341 Pharmacologic Targets on the Female Urethra Canda, A.E. (Manisa); Cinar, M.G.; Turna, B. (Izmir); Sahin, M.O. (Manisa)

Original Papers

355 Prevalence of Urinary Incontinence in the 12-Month Postpartum Period and Related Risk Factors in Turkey Ege, E.; Akın, B.; Altuntuğ, K.; Benli, S.; Ariöz, A. (Konya)

362 Nocturnal Enuresis in Turkey: Prevalence and Accompanying Factors in Different Socioeconomic Environments Carman, K.B.; Ceran, O.; Kaya, C.; Nuhoglu, C.; Karaman, M.I. (Istanbul)

367 Cytokine Therapy Response as a Selection Criterion for Cytoreductive Nephrectomy in Metastatic Renal Clear-Cell Carcinoma of Intermediate Prognosis. Results and Conclusions from a Combined Analysis

Bex, A.; Haanen, J.B.A.G.; Vyth-Dreese, F.A.; Horenblas, S.; de Gast, G.C. (Amsterdam)

372 Activation of PI3K Is Associated with Reduced Survival in Renal Cell Carcinoma

Merseburger, A.S.; Hennenlotter, J.; Kuehs, U.; Simon, P.; Kruck, S.; Koch, E.; Stenzl, A.; Kuczyk, M.A. (Tübingen)

378 Urodynamic Evaluation in Diabetic Patients with Prostate Enlargement and Lower Urinary Tract Symptoms Dib, P.T.; Trigo-Rocha, F.; Gomes, C.M.; Srougi, M. (São Paulo)

383 Catheter-Assisted Transurethral Resection of the Prostate: A Novel Approach

Shih, H.-J.; Chow, Y.-C.; Huang, C.-J.; Su, Y.-H.; Lin, W.-C.; Yang, S. (Taipei)

389 Ultrasonographic and Computed Tomography Findings in Renal Suppurations: Performance Indicators and Risks for Diagnostic Failure

Stojadinović, M. (Kragujevac); Mićić, S. (Belgrade); Milovanović, D. (Kragujevac)

398 Comparative Promoter Methylation Analysis of p53 Target Genes in Urogenital Cancers

Christoph, F.; Hinz, S.; Weikert, S.; Kempkensteffen, C.; Schostak, M.; Miller, K.; Schrader, M. (Berlin)

405 Arsenic Methylation Capability, Heme Oxygenase-1 and NADPH Quinone Oxidoreductase-1 Genetic Polymorphisms and the Stage and Grade of Urothelial Carcinomas

Huang, S.K.; Chiu, A.W.-H. (Tainan/Taipei); Pu, Y.-S.; Huang, Y.-K.; Chung, C.-J.; Tsai, H.-J. (Taipei); Yang, M.-H. (Hsinchu); Chen, C.-J.; Hsueh, Y.-M. (Taipei)

413 Does the Expression of Fascin-1 and Tumor Subclassification Help to Assess the Risk of Recurrence and Progression in T1 Urothelial Urinary Bladder Carcinoma?

Soukup, V.; Babjuk, M.; Dušková, J.; Pešl, M.; Szakáczová, M.; Zámečník, L.; Dvořáček, J. (Prague) 
419 Prevalence of Prostate Cancer in End-Stage Renal Disease Patients

Kamata, T.; Fushimi, K. (Tokyo)

425 Kohki Tea Protects the Rabbit Bladder from Ischemia/ Reperfusion-Induced Contractile Dysfunction Levin, R.M.; Leggett, R.E.; Whitbeck, C. (Albany, N.Y.); Matsumoto, S (Osaka); Ohto, N.; Ikeda, T.; Mizutani, K.; Higurashi, A. (Onomichi)

431 Gonadotropin-Releasing Hormone (GnRH) and GnRH Receptor in Bladder Cancer Epithelia and GnRH Effect on Bladder Cancer Cell Proliferation

Bahk, J.Y.; Kim, M.O.; Park, M.S.; Lee, H.Y.; Lee, J.-H. (Jinju); Chung, B.C.; Min, S.K. (Seoul)

Letter to the Editor

439 An Ancillary Method for Intraoperative Antegrade Stent Placement

Akyol, I. (Istanbul)

Case Reports

440 Page Kidney Phenomenon Presenting as Acute Renal Failure after Partial Nephrectomy: A Case Report and Review of the Literature

John, J.; Allen, S.; Perry, M.; Patel, H.R.H.; O’Brien, T. (London)
444 False Positive ${ }^{18}$ F-FDG PET Scan in Adrenal Oncocytoma Acar, C.; Akkas, B.E.; Sen, I.; Sozen, S.; Kitapci, M.T. (Ankara)

448 Renal Toxicity following Zoledronic Acid Reversed with Ibandronate in a Prostate Cancer Patient with Bone Metastases Joensuu, T.K. (Helsinki)

451 Neoadjuvant Therapy with Sorafenib in Advanced Renal Cell Carcinoma with Vena Cava Extension Submitted to Radical Nephrectomy

Di Silverio, F.; Sciarra, A.; Parente, U.; Andrea, A.;

Von Heland, M.; Panebianco, V.; Passariello, R. (Rome)

Clinical Comment

454 Comment on Di Silverio et al.: Neoadjuvant Therapy with Sorafenib in Advanced Renal Cell Carcinoma with

Vena cava Extension Submitted to Radical Nephrectomy. Urol Int 2008;80:451-453

Hakenberg, O.W. (Rostock)

447 Erratum

455 Author Index Vol. 80, 2008

458 Subject Index Vol. 80, 2008 